\title{
Increased nitric oxide in exhaled air of normal human subjects with upper respiratory tract infections
}

\author{
S.A. Kharitonov, D. Yates, P.J. Barnes
}

\begin{abstract}
Increased nitric oxide in exhaled air of normal human subjects with upper respiratory tract infections. S.A. Kharitonov, D. Yates, P.J. Barnes. @ERS Journals Ltd 1995. ABSTRACT: Viral infection may induce the expression of nitric oxide (NO) synthase, resulting in increased NO formation that has an antiviral effect. NO may be produced by various cells of the upper and lower respiratory tract, and may be detected in the exhaled air.

We have studied the levels of exhaled NO in 18 normal subjects during symptomatic upper respiratory tract infections and during recovery 3 weeks later. Exhaled NO was measured using a modified chemiluminescence analyser.

At the time of symptoms of upper respiratory tract infection, the peak exhaled NO values were $315 \pm 57 \mathrm{ppb}(\mathrm{mean} \pm \mathrm{SEM}$ ) and decreased to $87 \pm 9 \mathrm{ppb}$ during recovery. Recovery values of exhaled NO were similar to those reported in age-matched normal control subjects $(88 \pm 3 \mathrm{ppb}, \mathrm{n}=72)$.

These findings suggest that symptomatic upper respiratory tract infections markedly increase the concentration of NO in exhaled air. This may reflect the induction of nitric oxide synthase (NOS) in upper and lower respiratory tract, and may be relevant to viral exacerbations of asthma.

Eur Respir J., 1995, 8, 295-297.
\end{abstract}

Dept of Thoracic Medicine, National Heart and Lung Institute, London, UK.

Correspondence: P.J. Barnes

Dept of Thoracic Medicine

National Heart and Lung Institute

Dovehouse St

London SW3 6LY

UK

Keywords: Asthma exacerbation nitric oxide

nitric oxide synthase

upper respiratory tract infection

virus infection

Received: November 211994

Accepted after revision January 31995

This work was supported by the National Asthma Campaign. DY was supported by Astra Draco, Sweden.
Nitric oxide (NO) is important as a signalling molecule, and may play a key role in host defence and in the pathophysiology of airway diseases [1-3]. NO is generated from L-arginine by the enzyme NO synthase (NOS), which exists in at least three isoforms [4]. Constitutive forms of the enzyme are present in endothelial cells and neurons, but another isoform is induced in several types of cell after exposure to proinflammatory cytokines, endotoxin or oxidants. NO is detectable in the exhaled air of normal individuals [5], and may be derived predominantly from the upper respiratory tract $[6,7]$. Exhaled $\mathrm{NO}$ is increased in asthma and other inflammatory airways disease [8-10], and this may reflect expression of inducible NOS in airway epithelial cells [11]. This is supported by the fact that glucocorticoids inhibit the increase in exhaled NO in asthmatic patients, but have no effect in normal individuals [12].

Epithelial cells express inducible NOS in response to proinflammatory cytokines, such as tumour necrosis factor- $\alpha$ (TNF- $\alpha)$, interleukin-1 $\beta$ (IL-1 $\beta$ ) and interferon$\gamma(\mathrm{IFN}-\gamma)$ [13], and in response to oxidants [14]. Infection of epithelial cells with Bordatella pertussis results in a marked induction of NOS [15]. Induction of NOS is regulated by transcription factors, of which the most important is nuclear factor- $\kappa \mathrm{B}(\mathrm{NF}-\kappa \mathrm{B})[16]$. NF- $\mathrm{NB}$ is activated by proinflammatory cytokines and oxidants $[13,17]$. Since various viral infections may also induce $\mathrm{NF}-\kappa \mathrm{B}$, it is likely that viral infection of epithelial cells increases NO production. We have, therefore, studied whether upper respiratory tract infections (URTI), which are due to viruses such as rhinovirus and corona virus, increase the concentration of NO in the exhaled air of normal individuals.

\section{Subjects and methods}

\section{Subjects}

A total of 18 normal subjects ( 11 males) volunteered for this study. The age range was $27-40$ yrs (mean $34 \pm 1$ yrs). One subject was a current cigarette smoker (1-2 per day for 15-17 yrs), and two were ex-smokers for more than 5 yrs in the past. All subjects were studied at the time of a symptomatic URTI and had documented symptoms, such as rhinorrhoea, sneezing, congestion/ blocked nose, myalgia and generalized or frontal headache for at least 2 days prior to the investigation. Fourteen subjects had cough and chest pain accentuated by coughing. None of the subjects had a history of asthma or sinusitis, and none were taking medication (antihistamines, nonsteroidal anti-inflammatory drugs) at the time of study. In 72 nonsmoking normal controls (43 males; mean age $36 \pm 2 \mathrm{yrs}$ ) there was no history of URTI for at least 4 weeks prior to study, and no history of respiratory or cardiovascular disease. None of the subjects were receiving long-term medication. In 10 control subjects, 
exhaled NO measurements were repeated after 3 weeks in order to document reproducibility of the measurement.

\section{Study design}

Lung function parameters and exhaled NO were measured in all subjects on two occasions: 1-2 days after the onset of URTI symptoms; and 3 weeks later when they were asymptomatic. The age- and sex-matched normal control group was used as a reference group for comparison regarding the exhaled NO levels.

\section{Lung function measurements}

Lung function parameters (forced expiratory volume in one second $\left(\mathrm{FEV}_{1}\right)$ and forced vital capacity (FVC)) were measured by spirometry (Vitalograph, Buckingham, UK).

\section{Nitric oxide measurements}

Exhaled NO was measured on a chemiluminescence analyser (Dasibi Environmental Corporation, Glendale, California, USA) sensitive to NO from 2-4,000 parts per billion ( $\mathrm{ppb}$, by volume), adapted for on-line recording of NO concentration. This feature obviates the need for collection in a reservoir, with its variable loss of reactive NO, and gives greater sensitivity and reproducibility [8]. Subjects were asked to produce a slow vital capacity manoeuvre over 30-45 s into wide-bore Teflon tubing. NO was sampled continuously. The baseline value at each visit was measured after at least 15 min quiet rest. Three successive recordings were made at 2 min intervals and the highest of these was used. Results were displayed on a chart recorder and compared with the signal generated from a calibration mixture of NO (89 ppb) in nitrogen. Area under the curve of concentration traces was highly correlated with the peak value $(r=0.98)$; peak values were, therefore, used in all calculations. Ambient air NO was recorded before each breath.

\section{Statistical evaluation}

All the results were expressed as the mean士SEM. Comparisons between groups were made by two-way analysis of variance (ANOVA). A p-value of less than 0.05 was considered significant.

\section{Results}

Mean peak exhaled NO concentration was $88 \pm 3 \mathrm{ppb}$ in normal subjects (the control group). In subjects with URTI the peak exhaled NO was significantly higher $(315 \pm 57 \mathrm{ppb} ; \mathrm{p}<0.001)$ during the acute phase of URTI (table 1); whereas, peak NO values in subjects who had recovered from URTI did not differ significantly from
Table 1. - Exhaled nitric oxide during and after upper respiratory tract infections

\begin{tabular}{lcc}
\hline & URTI & Recovery \\
\hline Exhaled NO ppb & $315 \pm 57$ & $87 \pm 9^{*}$ \\
FEV $_{1} l$ & $4.8 \pm 0.13$ & $4.8 \pm 0.27$ \\
FEV $_{1} \%$ pred & $93 \pm 6.7$ & $95 \pm 5.3$ \\
FVC $l$ pred & $5.1 \pm 0.46$ & $5.2 \pm 0.61$ \\
FVC \% pred & $98 \pm 3.6$ & $100 \pm 2.9$ \\
\hline
\end{tabular}

URTI: subjects after the onset of symptomatic upper respiratory infection; Recovery: subjects studied 3 weeks after recovery from URTI; NO: nitric oxide (parts per billion); $\mathrm{FEV}_{1}$ : forced expiratory volume in one second; FVC: forced vital capacity. Data are presented as mean \pm SEM of 18 subjects. *: $\mathrm{p}<0.001$, significance of difference from baseline.

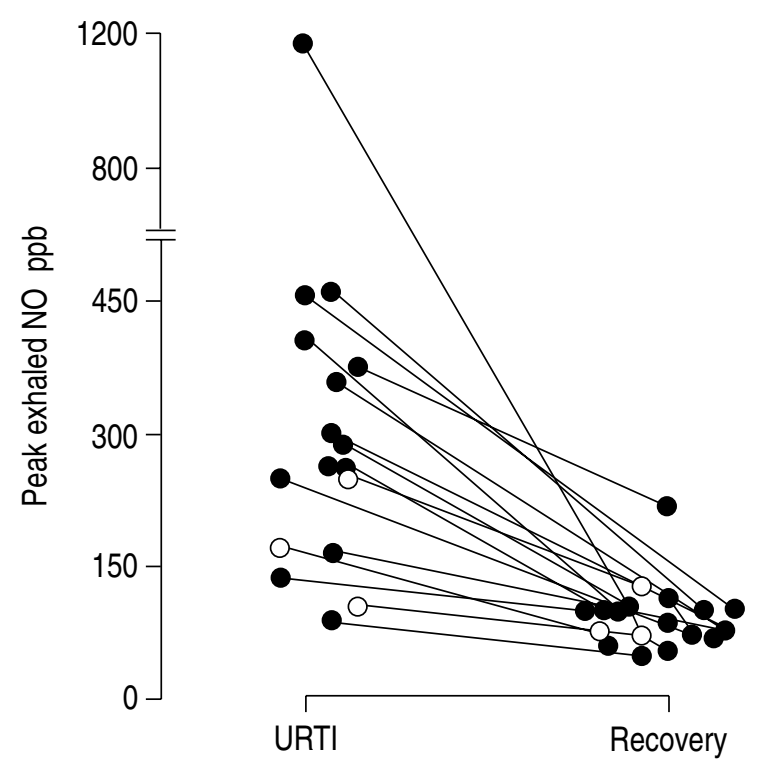

Fig. 1. - Individual values of exhaled nitric oxide (NO) in 18 normal subjects during a symptomatic upper respiratory tract infection (URTI) and 3 weeks afterwards when asymptomatic (Recovery). Open symbols represent a smoker and two ex-smokers. ppb: parts per billion.

those in normal subjects ( $87 \pm 9 \mathrm{ppb}$ ) (fig. 1). In 10 control subjects, exhaled NO values were reproducible over a 3 week period ( $81 \pm 6 \mathrm{ppb}$ at baseline, compared to $83 \pm 7$ ppb after 3 weeks). There was no significant difference in $\mathrm{FEV}_{1}$ and FVC during the acute phase of URTI (table $1)$.

\section{Discussion}

We have demonstrated that URTIs are associated with a marked increase in exhaled NO in normal individuals in the acute phase when symptoms are present, and that there is a reduction in exhaled NO after recovery to values that are similar to those reported in age-matched normal subjects in our laboratory. This suggests that URTI, presumably due to viral infection, increases production of $\mathrm{NO}$ in the respiratory tract. The exact source of exhaled NO is not known, but the increase in NO may be derived from nasal tissues or from the lower respiratory tract. It is of interest that a large proportion 
of the participants in this study complained of lower respiratory tract symptoms, including cough and chest pain accentuated by coughing, indicating that the lower respiratory tract was likely to have been involved.

It is difficult to confirm respiratory virus infections serologically, and recently developed polymerase chain reaction (PCR) techniques are not widely available [18]. We therefore based our diagnosis of URTI on clinical symptoms of blocked nose and lower respiratory symptoms, which improved after a few days.

NO plays an important role in nonspecific host defence and has antimicrobial activity against a wide variety of pathogens [3]. NO has inhibitory effects on viral replication and may mediate the antiviral effect of IFN- $\gamma[19$, 20]. Viral infections may induce NOS in a variety of cell types, including nasal and airway epithelial cells and macrophages, either via the activation of $\mathrm{NF}-\kappa \mathrm{B}$ in these cells or via the induction of proinflammatory cytokines. The increased NO production may then serve to limit the virus infection by inhibiting viral replication $[19,20]$.

URTIs are important in precipitating acute exacerbations of asthma [18, 21]. A variety of viruses are involved, including rhinovirus, respiratory syncytial virus, picornavirus, corona viruses and parainfluenza virus, together with atypical organisms, such as Mycoplasma pneumoniae and Chlamydia spp. It is tempting to speculate that the viral induction of NOS may contribute to an increase in airway inflammation, since high local concentrations of NO may have inflammatory effects in the airways [22]. We have previously reported that exhaled NO is elevated during exacerbations of asthma and falls during recovery [23]. The early use of oral or inhaled glucocorticoids during a URTI may limit the exacerbation by inhibiting induction of NOS [24].

The demonstration that URTIs are associated with a high level of exhaled NO indicates that caution should be applied when interpreting elevated values of exhaled $\mathrm{NO}$ and it is important to exclude measurements made at the time of an URTI.

\section{References}

1. Barnes PJ, Belvisi MG. Nitric oxide and lung disease. Thorax 1993; 48: 1034-1043.

2. Gaston B, Drazen JM, Loscalzo J, Stamler JS. The biology of nitrogen oxides in the airways. Am J Respir Crit Care Med 1994; 149: 538-551.

3. Liew FY, Cox FF. Nonspecific resistance mechanisms: the role of nitric oxide. Immunol Today 1991; 12: A17-A21.

4. Nathan C, Xie Q-W. Regulation of biosynthesis of nitric oxide. J Biol Chem 1994; 269: 13725-13728.

5. Gustafsson LE, Leone AM, Persson M-G, Wiklund NP, Moncada S. Endogenous nitric oxide is present in the exhaled air of rabbits, guinea-pigs and humans. Biochem Biophys Res Commun 1991; 181: 852-857.

6. Gerlach H, Rossaint R, Pappert D, Knorr M, Falke KJ.
Autoinhalation of nitric oxide after endogenous synthesis in nasopharynx. Lancet 1994; 343: 518-519.

7. Lundberg JON, Weitzberg E, Nordvall SL, Kuylenstierna R, Lundberg JM, Alving K. Primarily nasal origin of exhaled nitric oxide and absence in Kartagener's syndrome. Eur Respir J 1994; 7: 1501-1504.

8. Kharitonov SA, Yates D, Robbins RA, Logan-Sinclair $\mathrm{R}$, Shinebourne E, Barnes PJ. Increased nitric oxide in exhaled air of asthmatic patients. Lancet 1994; 343: 133-135.

9. Persson MG, Zetterstrom O, Argenius V, Ihre E, Gustafsson LE. Single-breath oxide measurements in asthmatic patients and smokers. Lancet 1994; 343: 146-147.

10. Kharitonov SA, Wells AU, O'Connor BJ, Hansell D, Cole PJ, Barnes PJ. Elevated levels of exhaled nitric oxide in bronchiectasis. Am J Respir Crit Care Med 1995; (in press).

11. Hamid Q, Springall DR, Riveros-Moreno V, et al. Induction of nitric oxide synthase in asthma. Lancet 1993; 342: 1510-1513.

12. Kharitonov SA, Yates DH, Robbins RA, Thomas PS, Barnes PJ. Corticosteroids decrease exhaled nitric oxide. Am J Respir Crit Care Med 1994; 149: A 201.

13. Robbins RA, Barnes PJ, Springall DR, et al. Expression of inducible nitric oxide synthase in human bronchial epithelial cells. Biochem Biophys Res Commun 1994; 203: 209-218.

14. Adcock IM, Brown CR, Kwon OJ, Barnes PJ. Oxidative stress induces NF- $\mathrm{KB}$ DNA-binding and inducible NOS mRNA in human epithelial cells. Biochem Biophys Res Commun 1994; 199: 1518-1524.

15. Heiss LN, Lancaster JR, Corbett JA, Goldman WE. Epithelial autotoxicity of nitric oxide: role in the respiratory cytopathology of pertussis. Proc Natl Acad Sci USA 1994; 91: 267-270.

16. Xie Q-W, Kashiwarbara Y, Nathan C. Role of transcription factor NF- $\kappa \mathrm{B} / \mathrm{Rel}$ in induction of nitric oxide synthase. J Biol Chem 1994; 269: 4705-4708.

17. Schreck R, Rieber P, Baeurle PA. Reactive oxygen intermediates as apparently widely used messengers in the activation of the NF- $\mathrm{BB}$ transcription factor and HIV1. EMBO J 1991; 10: 2247-2258.

18. Johnston SL, Bardin PG, Pattemore PK. Viruses as precipitants of asthma symptoms. Clin Exp Allergy 1993; 9: 236-246.

19. Croed KD. Evidence for antiviral effect of nitric oxide: inhibition of herpes simplex type 1 replication. J Clin Invest 1993; 91: 2446-2452.

20. Karupiah G, Xie W-W, Buller RML, Nathan C, Duarte C, MacMicking JC. Inhibition of viral replication by interferon- $\gamma$ induced nitric oxide synthase. Science 1993; 261: $1445-1448$.

21. Nicholson KG, Kent J, Ireland DL. Respiratory viruses and exacerbations of asthma in adults. Br Med J 1993; 307: 982-986.

22. Barnes PJ, Liew FY. Nitric oxide and asthmatic inflammation. Immunol Today 1995; (in press).

23. Kharitonov SA, Yates D, Robbins RA, Logan-Sinclair $\mathrm{R}$, Shinebourne E, Barnes PJ. Increased nitric oxide in exhaled air of asthmatic patients. Am J Respir Crit Care Med 1994; 149: A198.

24. Connett G, Lenney W. Prevention of viral induced asthma attacks using inhaled budesonide. Arch Dis Child 1993; 68: 85-87. 